\title{
Protection of aluminium alloys from atmospheric corrosion by thin films of inhibitors
}

\author{
A.M. Semiletov \\ A.N. Frumkin Institute of Physical Chemistry and Electrochemistry, Russian Academy \\ of Sciences, Leninsky pr. 31, Moscow, 119071 Russian Federation \\ E-mail:semal1990@mail.ru
}

\begin{abstract}
Some prospects for protection of aluminum alloys by corrosion inhibitors such as carboxylates and trialkoxysilanes are considered. The efficiency of inhibition of anodic dissolution of $\mathrm{Al}$ alloys by these compounds in a neutral borate buffer solution containing chlorides ( $\mathrm{pH}$ 7.4) was investigated. The protective capability of the layers obtained was estimated by an express method (drop test method) and by tests in a heat and moisture cabinet, and in a salt fog cabinet. The efficiency of treatment of Al alloys by aqueous solutions of organic inhibitors was compared with the protective ability of chromate films. It is shown that the passivation of Al alloys by the composition of oleyl sarcosinate with aminoethylaminopropyl-trimethoxysilane at a ratio of $3: 1$ is an efficient protection method even under salt fog conditions.
\end{abstract}

Key words: corrosion, aluminum and its alloys, corrosion inhibitors, trialkoxysilanes, carboxylates.

Received: October 5, 2017. Published: October 19, 2017.

doi: $\underline{10.17675 / 2305-6894-2017-6-4-5}$

\section{Introduction}

Aluminum alloys are widely applied as a structural material in aviation industry, automotive industry and shipbuilding. At present, conversion and paint coatings are used to protect Al alloys against corrosion [1]. Previously, hexavalent chromium compounds were widely used as corrosion inhibitors (CI) to increase the protective properties of coatings on Al alloys. The high efficiency of chromates is due not only to their ability to undergo reduction with formation of insoluble Cr compounds, but also to the ability to heal the coating defects that are formed during operation of items. The problem of self-healing of protective coatings on Al alloys, as well as on other metals, is very relevant as the use of chromates is rejected.

In some cases chromates were replaced by non-toxic organic CIs that provide even higher protection [2-5]. Passivating layers formed by organic CIs in aqueous solutions have proved themselves efficient in the protection of steel, copper, and copper alloys [611]. The protection of aluminum and its alloys by organic CIs is less explored, primarily due to the fact that chemisorption of organic compounds on them occurs less commonly. 
The adsorption of organic CIs on aluminum alloys was most often investigated with surfactants, such as salts of oleic acid [2] or dioctyl ester of phosphoric acid (DOPh), as examples $[12,13]$. In many respects this is due to the difficulties of experimental separation of the effects of alloy oxidation that occurs in aqueous solutions and of inhibitor adsorption itself.

As shown recently, not only higher amino acids, carboxylates and alkylphosphonates, but also organosilicon compounds - trialkoxysilanes (TAS) - are also very attractive as efficient passivators [14].

The high efficiency of TAS in the protection of Al and its alloys has been shown in a number of papers [15-18]. The adsorption of vinyltriethoxysilane (VTES) and aminopropyltriethoxysilane from aqueous solutions on Al surface was studied in [15]. It was shown that these TAS are chemisorbed on the Al surface. Corrosion tests of Al modified by VTES in $0.01 \mathrm{M} \mathrm{NaCl}$ showed that the siloxane layer prevents the occurrence of corrosion for 10 days.

It was found in [16] that the film formed by methacryloxypropyl trimethoxysilane inhibits general and local corrosion of pure $\mathrm{Al}$ in $3.5 \% \mathrm{NaCl}$ by forming an $\mathrm{Al}-$ siloxane polymer film.

The use of TAS was found to be very efficient not only in aqueous solutions but also as a VCI. The high protective ability of a coating formed from aminosilane vapors in the protection of mild steel, $\mathrm{Cu}, \mathrm{Zn}$ and $\mathrm{Al}$ alloy D16 against atmospheric corrosion has been shown [18].

Higher fatty acids and their salts are widely used As efficient CIs of Al and its alloys and for giving hydrophobic properties to Al surfaces. Sodium decanoate was used as a CI of aluminum alloy $2024(4.5 \% \mathrm{Cu}, 1.0 \% \mathrm{Mg}, 0.5 \% \mathrm{Mn})$ [19]. At $C_{\text {in }}=0.05 \mathrm{~mol} / \mathrm{L}$ in a solution containing $0.1 \mathrm{~mol} / \mathrm{L} \mathrm{Na}_{2} \mathrm{SO}_{4}$, it showed not only high protective properties according to electrochemical impedance spectroscopy (EIS), but also it gave hydrophobicity to the alloy surfaces (contact angle $\Theta_{c}=115^{\circ}$ ) after exposure for at least $1 \mathrm{~h}$ in this solution.

In [20], the superhydrophobization ( $\mathrm{SH})$ of an $\mathrm{Al}-\mathrm{Cu}-\mathrm{Mg}$ alloy surface after $24 \mathrm{~h}$ of exposure in a solution of $\mathrm{SA}$ and $N, N^{\prime}$-dicyclohexylcarbodiimide in $n$-hexane and subsequent drying in air was reported; the $\Theta_{c}$ value was $156^{\circ}$. When a sample of the $\mathrm{Al}$ alloy with superhydrophobized surface was immersed in water for 20 days, $\Theta_{c}$ decreased to $147^{\circ}$. It was concluded that the superhydrophobized surface of the Al alloy is stable for a long time and has excellent resistance to corrosive liquids, including acidic, alkaline and salt solutions.

In [21], samples of aluminum (99.9\%) were subjected to anodization and then treated by myristic acid $\left(\mathrm{CH}_{3}\left(\mathrm{CH}_{2}\right)_{12} \mathrm{COOH}\right)$ with $10 \%$ ethanol or with its $100 \%$ melt for $30 \mathrm{~min}$ at $70^{\circ} \mathrm{C}$. Then the samples were washed in ethanol $\left(70^{\circ} \mathrm{C}\right)$ and deionized water, and dried at $80^{\circ} \mathrm{C}$ for $1 \mathrm{~h}$ to reach $\Theta_{\mathrm{c}}=154^{\circ}$. It was shown that a combination of $\mathrm{Al}$ anodization for $2 \mathrm{~h}$ followed by treatment of samples in a myristic acid melt promotes the stabilization of the 
surface SH. Based on an analysis of electrochemical results, it was concluded that corrosion of aluminum is efficiently inhibited by the formation of a stable superhydrophobic film.

S.V. Oleynik $[22,23]$ showed the high efficiency of a carboxylate-based inhibitor IFKhAN-25 in the protection of Al alloys. Treatment of an Al alloy after chemical or plasma oxidation with IFKhAN-25 solution increased the protective properties of coatings in chloride solutions. It was assumed that the modification of the coatings by the CI increased the contribution of hydrophobization to an increase in the protective properties of the coatings.

The purpose of this work is to show the possibility of protection of Al alloys from atmospheric corrosion by thin passivating layers created from aqueous solutions of carboxylic acid salts and TAS and to compare their efficiency with films formed from a chromate solution.

\section{Experimental}

Corrosion and electrochemical tests were conducted on samples of $\mathrm{Al}$ alloys $\mathrm{AMg6}$, D16 and AD31 whose compositions are presented in Table 1. Before the experiments the samples were scraped by sandpaper of various roughness and degreased with acetone.

Table 1. Composition of $\mathrm{Al}$ alloys.

\begin{tabular}{ccccccccccc}
\hline & Al & Fe & Si & Mn & $\mathbf{C r}$ & $\mathbf{T i}$ & $\mathbf{C u}$ & $\mathbf{M g}$ & $\mathbf{Z n}$ & $\mathbf{B e}$ \\
\hline AMg6 & $\begin{array}{c}91.1- \\
93.68\end{array}$ & $\leq 0.4$ & $\leq 0.4$ & $0.5-0.8$ & - & $\begin{array}{c}0.02- \\
0.1\end{array}$ & $\leq 0.1$ & $5.8-6.8$ & $\leq 0.2$ & $\begin{array}{c}0.0002- \\
0.005\end{array}$ \\
\hline D16 & $\begin{array}{c}90.9- \\
94.7\end{array}$ & $\leq 0.5$ & $\leq 0.5$ & $0.3-0.9$ & $\leq 0.1$ & $\leq 0.15$ & $3.8-4.9$ & $1.2-1.8$ & $\leq 0.25$ & - \\
\hline AD31 & $\begin{array}{c}97.65- \\
99.35\end{array}$ & $\leq 0.5$ & $0.4-0.6$ & $\leq 0.1$ & $\leq 0.1$ & $\leq 0.15$ & $\leq 0.1$ & $\begin{array}{c}0.45- \\
0.9\end{array}$ & $\leq 0.2$ & - \\
\hline
\end{tabular}

The following compounds were studied as CIs: sodium salts of higher carboxylic acids such as oleic $\left[\mathrm{CH}_{3}\left(\mathrm{CH}_{2}\right)_{7} \mathrm{CH}=\mathrm{CH}\left(\mathrm{CH}_{2}\right)_{7} \mathrm{COONa}\right]$ (SOL) and oleyl sarcosine $\left[\mathrm{CH}_{3}\left(\mathrm{CH}_{2}\right)_{7} \mathrm{CH}=\mathrm{CH}\left(\mathrm{CH}_{2}\right)_{7} \mathrm{CON}\left(\mathrm{CH}_{3}\right) \mathrm{CH}_{2} \mathrm{COONa}\right]$ (SOS), as well as the following TAS: vinyltrimethoxysilane (VS) $\quad\left[\mathrm{H}_{2} \mathrm{C}=\mathrm{CH}-\mathrm{Si}\left(\mathrm{OCH}_{3}\right)_{3}\right]$ and aminoethylaminopropyltrimethoxysilane (AEAPTS) $\left[\mathrm{H}_{2} \mathrm{~N}-\left(\mathrm{CH}_{2}\right)_{2}-\mathrm{NH}-\left(\mathrm{CH}_{2}\right)_{3}-\mathrm{Si}\left(\mathrm{OCH}_{3}\right)_{3}\right]$. SOL was investigated as the "pure" grade sodium salt, while SOS was a concentrated $(60 \%)$ solution of the sodium salt. The working concentrates of TAS were prepared by dissolving in distilled water (AEAPTS) and isopropyl alcohol (VS) with continuous stirring for 30 minutes.

The passivating layers on metals were formed in aqueous solutions for $10 \mathrm{~min}$, at room temperature $\left(t=20 \pm 2^{\circ} \mathrm{C}\right)$ or at $60^{\circ} \mathrm{C}$, with constant stirring, followed by drying the samples in air. In certain cases, in the treatment of $\mathrm{Al}$ alloys, the passivating solution was 
neutralized so that the $\mathrm{pH}$ did not exceed 8.2, since partial dissolution of the oxide film on the surface of $\mathrm{Al}$ alloys is possible at $\mathrm{pH} \geq 8.2$.

In electrochemical studies, a borate buffer solution with $\mathrm{pH} 7.4$ containing $0.01 \mathrm{~mol} / \mathrm{L}$ $\mathrm{NaCl}$ served as the background solution. Anodic polarization curves of Al alloys were recorded in a glass cell with divided electrode spaces using a PI 50-1.1 potentiostat. The electrode potentials $(E)$ were measured relative to the silver chloride electrode and recalculated to the hydrogen scale. A platinum Pt auxiliary electrode was employed.

Electrodes made of $\mathrm{Al}$ alloys were not pre-activated. Instead, they were kept for $1 \mathrm{~h}$ in the background solution. After the free corrosion potential $\left(E_{\text {cor }}\right)$ stabilized, a CI was injected into the cell. At the new $E_{\text {cor }}$ value (that was set after $15 \mathrm{~min}$ ), the potentiostat was turned on and anodic polarization of the electrode was carried out. The pitting potential $\left(E_{\mathrm{pt}}\right)$ was determined on the anodic polarization curves by the current density $\left(i_{\mathrm{a}}\right)$ jump, with subsequent visual identification of pitting on the electrode.

In addition, $E_{\mathrm{pt}}$ was determined on electrodes treated for $10 \mathrm{~min}$ in passivating CI solutions. Anodic polarization curves were recorded in a borate buffer solution ( $\mathrm{pH}$ 7.4) containing $1 \mathrm{mmol} / \mathrm{L} \mathrm{NaCl}$. A CI-treated electrode was air-dried and then immersed in the solution, then anodic polarization was started immediately. The protective properties of the passivation layers of the CIs were evaluated by an increase in $E_{\mathrm{pt}}$ compared to the same value measured without inhibitor treatment.

The protective ability of coatings was determined by three methods: drop test, exposure in a heat and moisture cabinet (HMC), and salt fog cabinet (SFC). In the first (accelerated) tests, a drop of a solution containing $30 \mathrm{~g} / \mathrm{L}$ of potassium dichromate in $2.0 \mathrm{M}$ $\mathrm{HCl}$ was applied onto the surface of $\mathrm{Al}$ alloys studied. Then the times until the first drop color changes $\left(\tau_{1}\right)$ and until complete drop color change from orange to green $\left(\tau_{2}\right)$ were determined. The coating stability was assessed by the time elapsed before the color change. The test was carried out in 3 different locations on the sample and the mean value was calculated.

Tests under high humidity conditions were carried out in an HMC. The cabinet was maintained at $100 \%$ air relative humidity, and the temperature was kept at $t=(40 \pm 2)^{\circ} \mathrm{C}$ for 8 hours a day, then heating was turned off and abundant water condensate formed on the samples as a result. During the tests, the plates were inspected at equal time intervals since the beginning of the tests but at least once a day, so as to determine the time until the first corrosive damage $\left(\tau_{\text {cor }}\right)$.

The tests in an SFC were performed with samples treated only by solutions of the most efficient passivators previously identified by the tests described above. $5 \% \mathrm{NaCl}(\mathrm{pH}$ 6.5-7.2) was used as the salt solution. The salt solution was sprayed inside the cabinet with the test samples to form a fog. The cabinet worked continuously in cyclic mode (one cycle included spraying the salt solution for $15 \mathrm{~min}$, then the cabinet was turned off for $45 \mathrm{~min}$, then the cycle was repeated). The tests were carried out at $t=35^{\circ} \mathrm{C}$ and $95-100 \%$ humidity. Inspection of the samples was carried out three times a day to determine the time of appearance of the first corrosion damage $\left(\tau_{\mathrm{cor}}\right)$. 


\section{Results and Discussion}

\section{AMg6 alloy}

In a borate buffer solution containing $10 \mathrm{mmol} / \mathrm{L} \mathrm{NaCl}$, the $\mathrm{Al}$ electrode of $\mathrm{AMg} 6$ alloy is passive due to the presence of an oxide film on the surface. After $1 \mathrm{~h}$ of exposure in the solution, its $E_{\text {cor }}$ was $-0.54 \mathrm{~V}$ (Figure 1). Under anodic polarization, the electrode undergoes local depassivation by chlorides, $E_{\mathrm{pt}}=-0.40 \mathrm{~V}$. If $1.0 \mathrm{mmol} / \mathrm{L} \mathrm{K}_{2} \mathrm{Cr}_{2} \mathrm{O}_{7}$ is added, the free corrosion potential $E_{\text {cor }}$ shifts to more negative values, while $E_{\mathrm{pt}}$ changes only a little $(-0.38 \mathrm{~V})$. However, the anti-pitting basis, i.e., the difference $E_{\mathrm{pt}}-E_{\mathrm{cor}}$, equals $0.30 \mathrm{~V}$, which is noticeably higher than the similar value in the background solution $(0.14 \mathrm{~V})$. This indicates that chromate has an inhibitory effect and inhibits the cathodic reaction on the alloy.

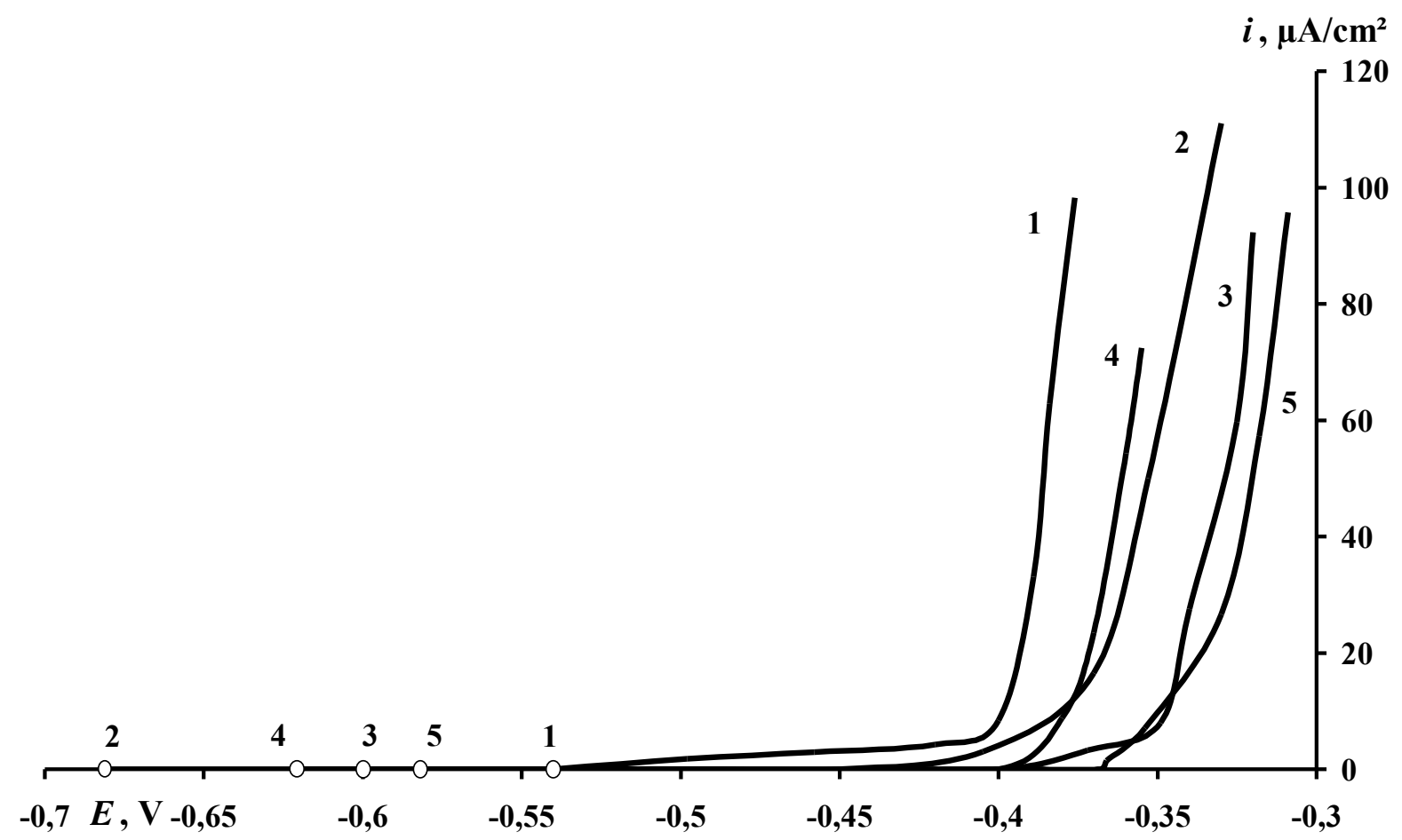

Figure 1. Anodic polarization curves of $\mathrm{Al}$ alloy $\mathrm{AMg} 6$ in borate buffer solution with $\mathrm{pH} 7.4$ containing $10 \mathrm{mM} \mathrm{NaCl}$ and doped with $1.0 \mathrm{mmol} / \mathrm{L} \mathrm{CI}$ : $1-$ none; $2-\mathrm{K}_{2} \mathrm{Cr}_{2} \mathrm{O}_{7} ; 3-\mathrm{SOS} ; 4-$ SOL; 5 - SOS + AEAPTS $(3: 1)$.

It is known $[2,4]$ that higher carboxylates, SOL and SOS, are the most efficient CIs for passivation of ferrous and non-ferrous metals. The addition of $1.0 \mathrm{mmol} / \mathrm{L} \mathrm{SOL}$ or $1.0 \mathrm{mmol} / \mathrm{L} \mathrm{SOS}$ also displaces $E_{\text {cor }}$ in the negative direction, but $E_{\mathrm{pt}}$ increases only slightly, e.g., $E_{\mathrm{pt}}=-0.35 \mathrm{~V}$ for SOS. At the same time, the anti-pitting basis observed in the presence of SOL and SOS is smaller than in the case of chromate: $0.24 \mathrm{~V}$ and $0.25 \mathrm{~V}$, respectively. A mixed CI, SOS + AEAPTS (1.0 mM, 3:1), is not less efficient than SOS. 
However, passivation of metals is usually carried out in more concentrated solutions followed by drying of the surface [24]. In view of this, in the second series of experiments, anodic polarization of an $\mathrm{AMg} 6$ electrode was carried out after its treatment in a passivating solution containing $16 \mathrm{mmol} / \mathrm{L} \mathrm{CI}$ and drying in air.

After passivation in an aqueous solution containing $16 \mathrm{mmol} / \mathrm{L} \mathrm{CI}$, the protective effect in a more dilute chloride solution $(1.0 \mathrm{mmol} / \mathrm{L} \mathrm{NaCl})$ is evident (Figure 2). The increase in $E_{\mathrm{pt}}$ in comparison with the similar value without passivating treatment is 0.17 , 0.33 and $0.43 \mathrm{~V}$ for $\mathrm{K}_{2} \mathrm{Cr}_{2} \mathrm{O}_{7}$, SOL and SOS, respectively.

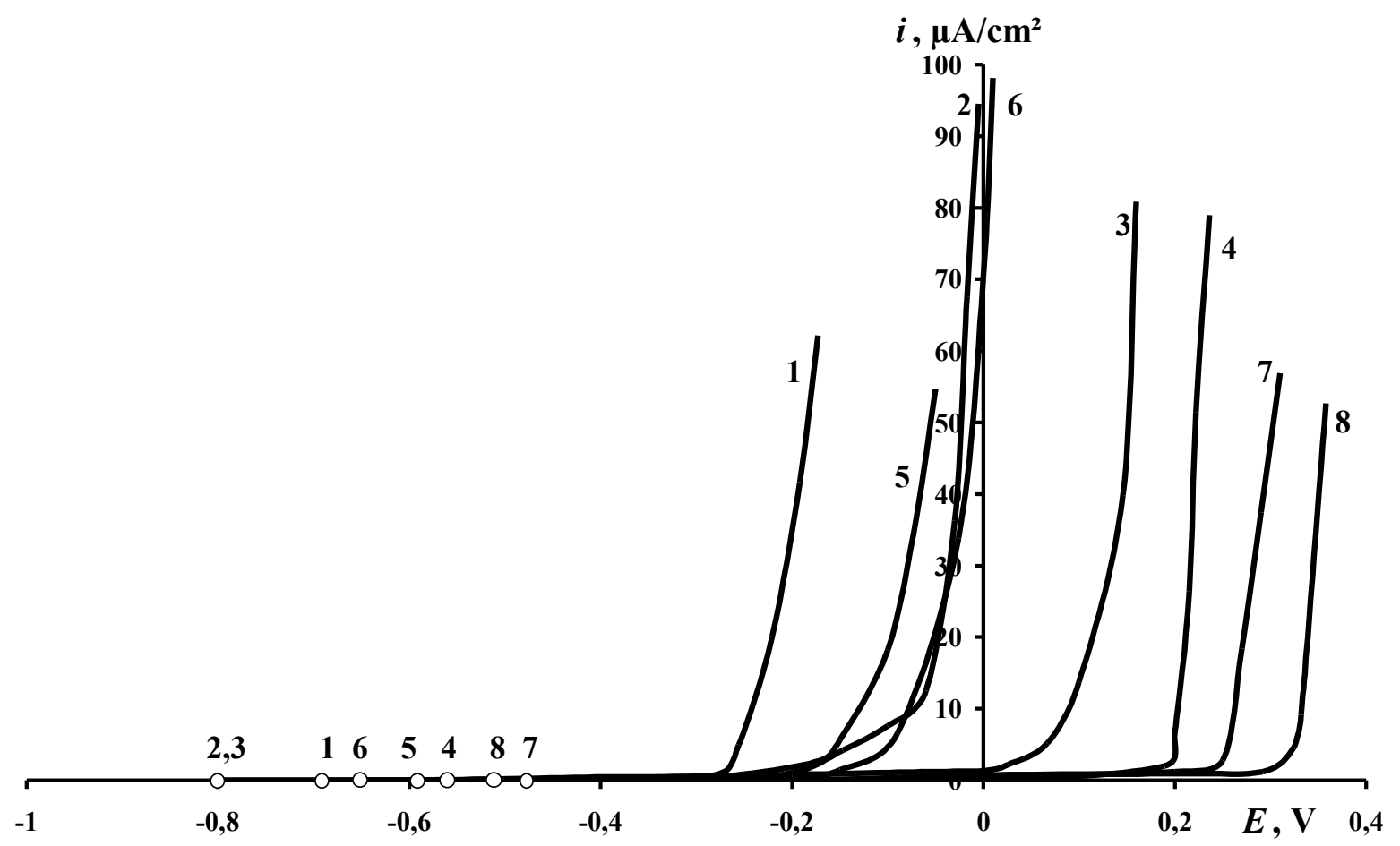

Figure 2. Anodic polarization curves of $\mathrm{Al}$ alloy AMg6 in borate buffer solution with $\mathrm{pH} 7.4$ containing $1 \mathrm{mmol} / \mathrm{L} \mathrm{NaCl}$ without treatment (1) and after its preliminary passivation in solutions of CI with $C_{\text {in }}=16 \mathrm{mmol} / \mathrm{L}: 2-\mathrm{K}_{2} \mathrm{Cr}_{2} \mathrm{O}_{7} ; 3$ - SOL; 4 - SOS; 5 - VS; 6 - AEAPTS; 7 - SOS+VS $(3: 1) ; 8$ - SOS+AEAPTS $(3: 1)$.

As shown previously [25], the efficiency of carboxylate CIs can be enhanced using TAS that, by themselves, are not efficient enough to prevent the local activation of AMg6 alloy. In fact, the $E_{\mathrm{pt}}$ value increases by only 0.18 or $0.26 \mathrm{~V}$ after treatment with aqueous solutions of VS or AEAPTS, respectively. However, if passivation is carried out in a solution of a mixture of SOS with VS or AEAPTS $(3: 1)$, then $\Delta E=E_{\mathrm{pt}}^{\mathrm{in}}-E_{\mathrm{pt}}^{\mathrm{bg}}$ reaches 0.53 and $0.59 \mathrm{~V}$, respectively. This effect indicates that treatment of AMg6 alloy in an aqueous solution of the SOS + AEAPTS formulation can surpass the protection provided by chromate passivation. 
To check this assumption, accelerated corrosion tests were carried out using G.V. Akimov's drop method. As can be seen from the results presented in Table 2, treatment in a potassium dichromate solution gives the best results at $t \sim 20^{\circ} \mathrm{C}$. Increasing the temperature to $60^{\circ} \mathrm{C}$ does not improve but weakens the protective properties of the chromate film. The adverse effect of a temperature increase is indicated by the results of corrosion tests in the heat and moisture cabinet.

Table 2. The results of corrosion tests of samples from Al alloy AMg6 pre-passivated in aqueous solutions of corrosion inhibitors by the drop test method, in a heat and moisture cabinet and in a salt fog cabinet.

\begin{tabular}{|c|c|c|c|c|c|c|}
\hline \multirow{2}{*}{$\begin{array}{c}\text { Composition of } \\
\text { the passivating } \\
\text { solutions, } \\
\text { mmol/L }\end{array}$} & \multirow{2}{*}{$\begin{array}{l}\text { Treatment } \\
\text { temperature, } \\
{ }^{\circ} \mathrm{C}\end{array}$} & \multirow{2}{*}{$\begin{array}{c}\text { pH of } \\
\text { solutions }\end{array}$} & \multicolumn{2}{|c|}{ Drop test } & \multicolumn{2}{|c|}{$\begin{array}{l}\text { Time to the appearance of } \\
\text { the first corrosion damage, } \\
\qquad \tau_{\text {cor }}, h\end{array}$} \\
\hline & & & $\begin{array}{c}\tau_{1}, \\
\text { min:sec }\end{array}$ & $\begin{array}{c}\tau_{2}, \\
\text { min:sec }\end{array}$ & HМС & SFC \\
\hline No treatment & - & - & $1: 00$ & $2: 15$ & 18 & 10 \\
\hline $16 \mathrm{~K}_{2} \mathrm{Cr}_{2} \mathrm{O}_{7}$ & 20 & 4.2 & $2: 00$ & $3: 05$ & 100 & 40 \\
\hline same as above & 60 & 4.2 & $1: 10$ & $2: 30$ & 76 & - \\
\hline $4 \mathrm{VS}$ & 20 & 6.5 & $1: 00$ & $2: 00$ & 72 & - \\
\hline $16 \mathrm{VS}$ & 20 & 6.6 & $2: 30$ & $4: 00$ & 170 & 15 \\
\hline 4 AEAPTS & 20 & 8.7 & $0: 50$ & $1: 50$ & 50 & - \\
\hline 16 AEAPTS & 20 & 9.0 & $1: 00$ & $2: 10$ & 96 & - \\
\hline same as above & 20 & 8.2 & $1: 40$ & $2: 30$ & 120 & 10 \\
\hline $16 \mathrm{SOL}$ & 60 & 8.0 & 3:00 & $5: 10$ & 128 & 50 \\
\hline $12 \mathrm{SOL}+4 \mathrm{VS}$ & 60 & 7.7 & $2: 50$ & $4: 00$ & 78 & - \\
\hline $\begin{array}{c}12 \mathrm{SOL}+4 \\
\text { AEAPTS }\end{array}$ & 60 & 8.3 & $1: 10$ & $2: 50$ & 176 & - \\
\hline $1 \mathrm{SOS}$ & 60 & 8.0 & $1: 00$ & $2: 00$ & - & - \\
\hline $4 \mathrm{SOS}$ & 60 & 8.0 & $1: 30$ & $4: 00$ & - & - \\
\hline $8 \mathrm{SOS}$ & 60 & 8.0 & $3: 30$ & $8: 20$ & - & - \\
\hline $16 \mathrm{SOS}$ & 60 & 7.9 & $4: 20$ & $10: 00$ & 200 & 56 \\
\hline $12 \mathrm{SOS}+4 \mathrm{VS}$ & 60 & 8.0 & $4: 00$ & $12: 45$ & 240 & 80 \\
\hline $\begin{array}{c}12 \mathrm{SOS}+4 \\
\text { AEAPTS }\end{array}$ & 60 & 9.4 & $3: 00$ & $11: 20$ & 304 & - \\
\hline same as above & 60 & 8.2 & $3: 30$ & $13: 40$ & 390 & 110 \\
\hline
\end{tabular}


Treatment of AMg6 alloy in aqueous solutions of TAS revealed a significant difference between different TAS. The passivating effect of VS, which is less stable and easily undergoes chemical transformations even in neutral solutions, is even slightly superior in the alloy protection to the treatment with a dichromate solution, at the same CI concentration of $16 \mathrm{mmol} / \mathrm{L}$. This is confirmed by the test results obtained in the heat and moisture cabinet. The disadvantage of this solution is its low stability, especially at $60^{\circ} \mathrm{C}$, where VS can form precipitates of hardly soluble compounds due to its chemical transformations. The aqueous solution of AEAPTS is much more stable, but its passivating effect is worse, but it is also improved is the solution is partially neutralized: although the drop test shows a slightly poorer result than chromate passivation, but samples treated with an aqueous AEAPTS solution demonstrate an even better performance in a heat and moisture cabinet.

SOL solutions can also be very efficient in the passivation of aluminum alloys [2]. It is not surprising that the drop test and HMC tests performed after treatment of $\mathrm{AMg} 6$ samples with an aqueous solution containing $16 \mathrm{mmol} / \mathrm{L}$ SOL demonstrate better corrosion resistance than after chromate passivation. Replacement of one-third of SOL with VS weakens the alloy protection, unlike similar replacement with AEAPTS.

Judging by the drop test and tests in the HMC, SOS is the best passivator. Even at two times lower concentration, $C_{\mathrm{SOS}}=8 \mathrm{mmol} / \mathrm{L}$, treatment with this $\mathrm{CI}$ solution is significantly superior to chromate passivation, while an increase in $C_{\mathrm{SOS}}$ to $16 \mathrm{mmol} / \mathrm{L}$ further enhances the alloy protection. It is interesting that in this case, replacement of part of SOS by VS and especially AEAPTS makes passivating treatment of AMg6 alloy more efficient. In fact, in an HMC, the films formed in a solution containing $12 \mathrm{mM}$ SOS + $4 \mathrm{mM}$ AEAPTS with $\mathrm{pH} 8.2$, prevent the appearance of the first corrosion damage under drastic conditions of abundant (daily) condensation of water on the samples for almost a 4 times longer period. Judging by the drop test, the corrosion after the appearance of its first manifestation also occurs more slowly than in the case of chromate passivation of the alloy. This is indicated by the $\tau_{1} / \tau_{2}$ ratio, which is 4.0 instead of 1.5 for chromate treatment.

Corrosion testing in SFC of samples subjected to passivating treatment in aqueous solutions of CIs is of course the most stringent method. However, even in this case, it can be seen that treatment by an aqueous solution of SOS is 1.4 times more efficient than chromate passivation (Table 2). SOL has a slightly weaker passivating effect, but it is not inferior to the efficiency of chromate. On the other hand, treatment by aqueous solutions of TAS itself is much less efficient than chromate passivation under salt spray conditions, and even in the case of treatment with an aqueous VS solution, the time before the appearance of the first corrosion damage does not exceed $15 \mathrm{~h}$. Use of the same formulations of SOS with TAS allows to significantly increase the efficiency of AMg6 alloy passivation. In fact, the time before the appearance of the first corrosion damage after treatment in a mixture of SOS + VS (3:1) and SOS + AEAPTS (3:1) is 80 and $110 \mathrm{~h}$, respectively.

In longer tests in an SFC, it was noted that SOS and its mixture with AEAPTS continue to inhibit corrosion damage for a longer time. As it is seen in the images of the 
samples obtained after 240 hours of testing (Figure 3), treatment with a solution containing $12 \mathrm{mM}$ SOS $+4 \mathrm{mM}$ AEAPTS is much more efficient than passivation by solutions of its components at the same concentration.

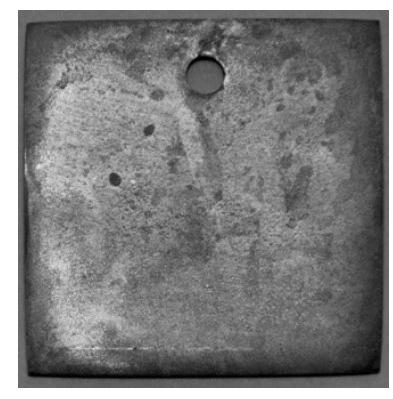

No treatment

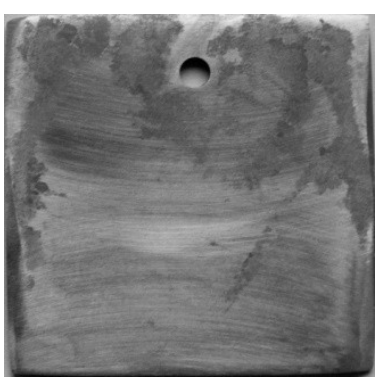

$16 \mathrm{mmol} / \mathrm{L}$ AEAPTS

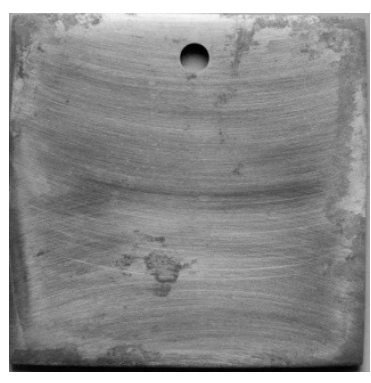

$16 \mathrm{mmol} / \mathrm{L} \mathrm{SOS}$

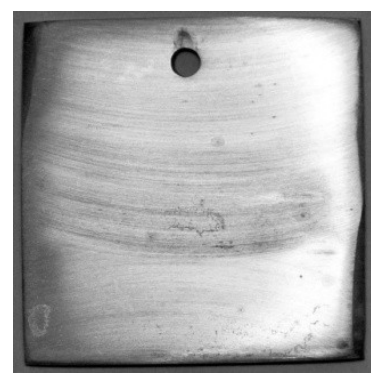

$12 \mathrm{mmol} / \mathrm{L} \mathrm{SOS}+$ $4 \mathrm{mmol} / \mathrm{L}$ AEAPTS

Figure 3. Images of samples of alloy AMg6 after 240 hours of testing in a salt fog cabinet.

\section{D16 alloy}

Under HMS conditions, the first corrosion damage on samples of aluminum alloy D16 appears after $8 \mathrm{~h}$ (Figure 4). Treatment of the alloy in a chromate solution at $20^{\circ} \mathrm{C}$ provides $\tau_{\text {cor }}=150 \mathrm{~h}$; an increase in temperature adversely affects the protective properties of the protective film obtained, $\tau_{\text {cor }}=98 \mathrm{~h}$.

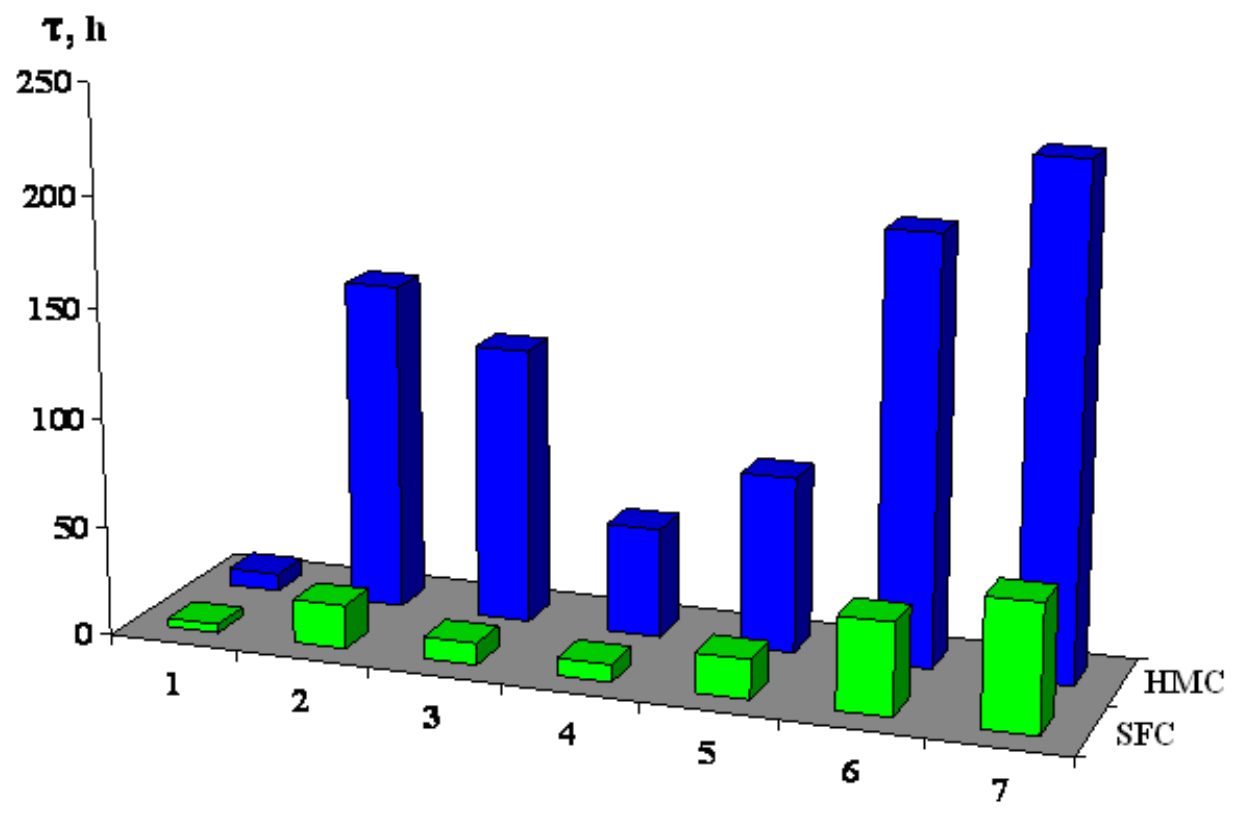

Figure 4. Time before the first corrosion damage ( $\left.\tau_{\text {cor }}\right)$ appears on samples of D16 alloy placed in an SFC or HMC without (1) and with preliminary passivation (2-7) in aqueous solutions of corrosion inhibitors at $C_{\text {in }}=16 \mathrm{mmol} / \mathrm{L}$ containing: $2-\mathrm{K}_{2} \mathrm{Cr}_{2} \mathrm{O}_{7} ; 3-\mathrm{VS} ; 4-$ AEAPTS; 5 - SOL; 6 - SOS; 7 - SOS +AEAPTS (3:1). 
Tests in an HMC have shown that the passivation of samples of D16 alloy by an aqueous solution of SOS at $\mathrm{C}_{\mathrm{in}}=16 \mathrm{mmol} / \mathrm{L}$ is inferior to chromate treatment, $\tau_{\text {cor }}=80 \mathrm{~h}$. SOS possesses a better protective ability than SOL, $\tau_{\text {cor }}=194 \mathrm{~h}$, which exceeds 1.3 -fold the protective ability of chromate passivation.

Treatment of D16 alloy in aqueous solutions of TAS revealed the advantage of VS over AEAPTS. Passivation in a solution of VS, which easily undergoes hydrolysis, provides $\tau_{\text {cor }}=126 \mathrm{~h}$ and is slightly inferior to the treatment in a chromate solution. Passivation in an aqueous solution of a more stable TAS, AEAPTS, is not so efficient: the $\tau_{\text {cor }}$ value does not exceed $50 \mathrm{~h}$.

Passivation in a solution of a mixed inhibitor with $C_{\text {in }}=16 \mathrm{mmol} / \mathrm{L} \mathrm{SOS}+$ AEAPTS (3:1) allows one to obtain films with the best protective properties and $\tau_{\text {cor }}=230 \mathrm{~h}$. The advantage of D16 alloy treatment with the mixture is also confirmed by an electrochemical estimation of pre-formed CI protective layers in borate buffer with $1 \mathrm{mmol} / \mathrm{L} \mathrm{NaCl}$ (Figure 5). Passivating treatment by a solution of $\mathrm{K}_{2} \mathrm{Cr}_{2} \mathrm{O}_{7}$ with $C_{\text {in }}=16 \mathrm{mmol} / \mathrm{L}$ shifts $E_{\text {cor }}$ by $0.2 \mathrm{~V}$ compared to $E_{\text {cor }}$ of the background sample, and the $\Delta E_{\mathrm{pt}}$ value changes only a little and is $\leq 0.1 \mathrm{~V}$. Treatment in AEAPTS and SOS solutions with $C_{\text {in }}=16 \mathrm{mmol} / \mathrm{L}$ slightly changes $E_{\text {cor }}$, but $E_{\mathrm{pt}}$ is higher than that after chromate treatment. The shift $\left(\Delta E_{\mathrm{pt}}\right)$ is 0.3 and $0.4 \mathrm{~V}$ for SOS and the SOS + AEAPTS mixture (3:1), respectively.

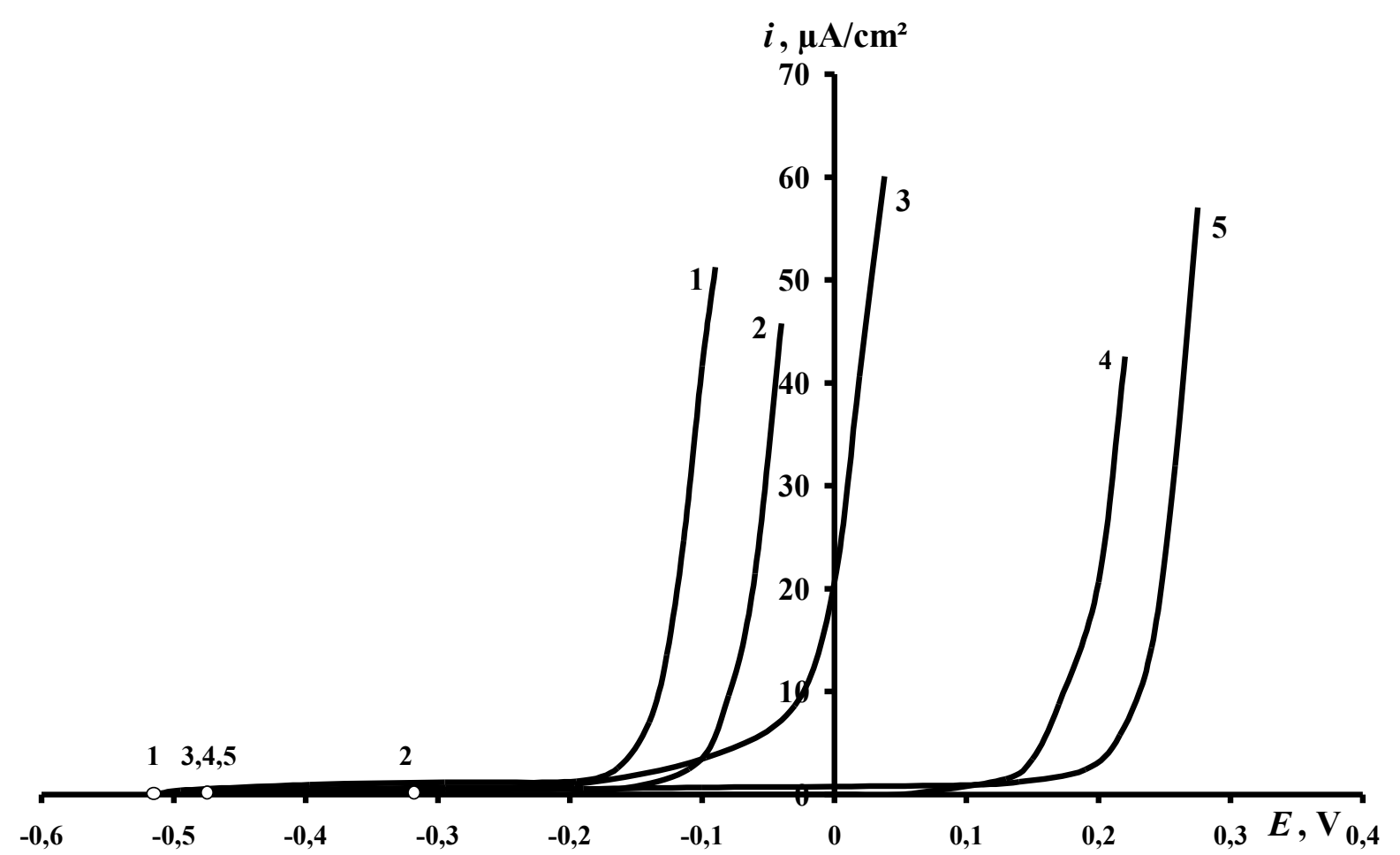

Figure 5. Anodic polarization curves of Al alloy D16 in borate buffer solution with pH 7.4 containing $1 \mathrm{mmol} / \mathrm{L} \mathrm{NaCl}$ without treatment (1) and after its preliminary passivation in CI solutions with $C_{\text {in }}=16 \mathrm{mmol} / \mathrm{L}: 2-\mathrm{K}_{2} \mathrm{Cr}_{2} \mathrm{O}_{7} ; 3-$ AEAPTS; $4-\mathrm{SOS} ; 5-\mathrm{SOS}+\mathrm{AEAPTS}$ (3:1). 
Corrosion tests under the most drastic conditions in an SFC have shown that treatment in aqueous solutions of organic CIs is not inferior to chromate passivation in terms of the protection efficiency of D16 alloy $\left(\tau_{\text {cor }}=20 \mathrm{~h}\right)$. Treatment with an aqueous solution of SOS with $C_{\text {in }}=16 \mathrm{mmol} / \mathrm{L}$ is 2.1 times more efficient than chromate passivation under neutral salt conditions fog $\left(\tau_{\text {cor }}=42 \mathrm{~h}\right)$. Small additions of VS and AEAPTS to SOS increase the protective properties of the films, and the time until the appearance of the first corrosion damage increases to $\tau_{\text {cor }}=55$ and $58 \mathrm{~h}$.

\section{AD31 alloy}

The first corrosion damage on the samples of the AD31 aluminum alloy under HMC conditions are observed after 26 hours, and under SFC conditions, $\tau_{\text {cor }}=8 \mathrm{~h}$ (Figure 6). Passivation with a $\mathrm{K}_{2} \mathrm{Cr}_{2} \mathrm{O}_{7}$ solution with $C_{\text {in }}=16 \mathrm{mmol} / \mathrm{L}$ provides protection of the AD31 alloy in an HMC for $\tau_{\text {cor }}=100 \mathrm{~h}$, and $\tau_{\text {cor }}=24 \mathrm{~h}$ in an SFC. Treatment in TAS solutions is inferior to passivation with a chromate solution, and $\tau_{\text {cor }}$ does not exceed $75 \mathrm{~h}$ for AEAPTS and $30 \mathrm{~h}$ for VS.

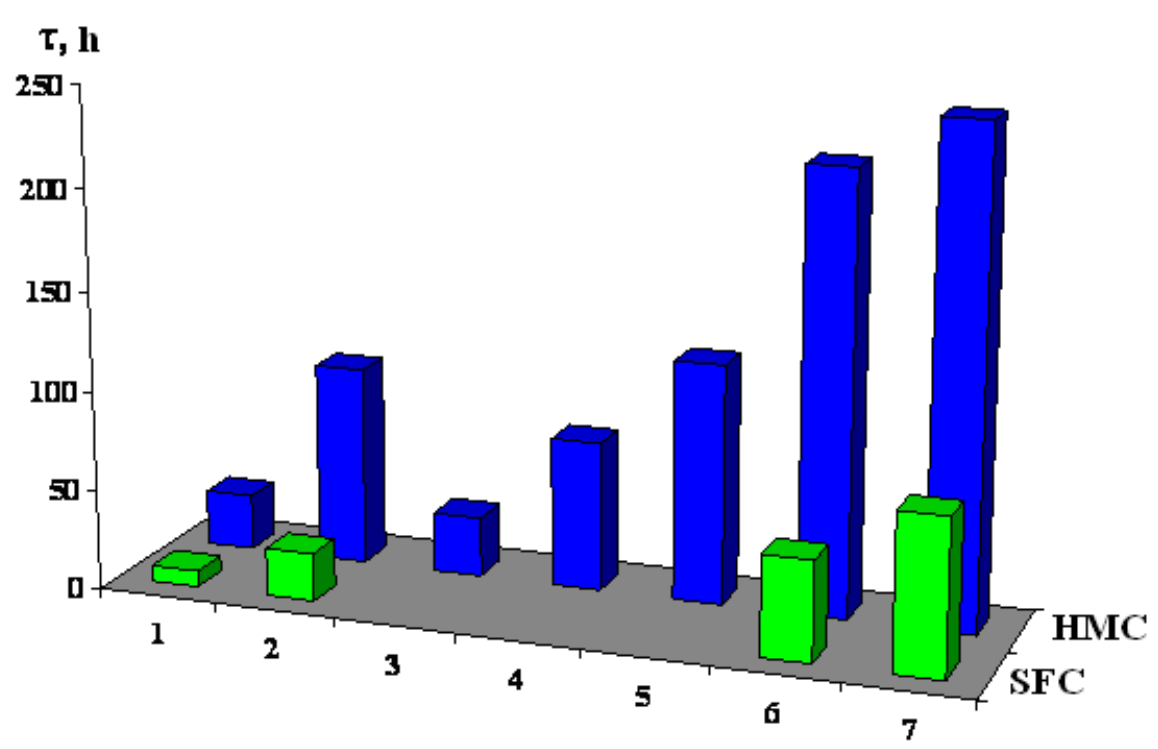

Figure 6. Time before the first corrosion damage $\left(\tau_{\text {cor }}\right)$ appears on samples of AD31 placed in an SFC or HMC without (1) and with preliminary passivation (2-7) in aqueous solutions of corrosion inhibitors at $C_{\text {in }}=16 \mathrm{mmol} / \mathrm{L}$ containing: $2-\mathrm{K}_{2} \mathrm{Cr}_{2} \mathrm{O}_{7} ; 3-\mathrm{VS} ; 4-\mathrm{AEAPTS} ; 5-$ SOL; 6 - SOS; 7 - SOS +AEAPTS (3:1).

The passivating treatment in solutions of carboxylate CIs is significantly superior to the treatment by TAS solutions in terms of protective properties. Passivation of the AD31 alloy in a SOL solution with $C_{\mathrm{in}}=16 \mathrm{mmol} / \mathrm{L}$ provides protection of the samples from corrosion in an HMC for 120 hours, and after treatment in a SOS solution with the same $C_{\mathrm{in}}, \tau_{\mathrm{cor}}=220 \mathrm{~h}$. Passivation by a mixed CI solution containing $12 \mathrm{mmol} / \mathrm{L} \mathrm{SOS}+$ $4 \mathrm{mmol} / \mathrm{L}$ AEAPTS allows one to obtain films with the best protective properties, both in 
an SFC $\left(\tau_{\text {cor }}=78 \mathrm{~h}\right)$ and in an HMC $\left(\tau_{\text {cor }}=246 \mathrm{~h}\right)$. The results of corrosion tests show that passivating treatment of samples of the AD31 alloy with a SOS + AEAPTS mixture $(3: 1)$ is 2.4-3.2 times more efficient than chromate treatment.

\section{Conclusions}

1. According to the results of polarization measurements, organic corrosion inhibitors SOL and SOS inhibit the anodic dissolution of aluminum alloy AMg6 in a neutral borate buffer solution containing $10 \mathrm{mmol} / \mathrm{L} \mathrm{NaCl}$.

2. Passivation of aluminum alloy surfaces in SOL and SOS solutions makes it possible to create passivating films that are not inferior to the protective properties of chromate films under conditions of corrosion tests (drop test, HMC and SFC).

3. Although VS and AEAPTS have some protective effect on the aluminum alloys studied, it is weaker than that of chromate, especially under SFC conditions. However, they can enhance the protective properties of sodium salts of higher carboxylic acids.

4. Passivation of aluminum alloys in an aqueous water solution of a SOS + AEAPTS mixed inhibitor in $3: 1$ ratio at $C_{\text {in }}=16 \mathrm{mmol} / \mathrm{L}$ is the most efficient method of corrosion prevention, not only under the conditions of high air humidity with daily condensation of moisture on the samples, but also under especially drastic SFC conditions.

\section{Acknowledgments}

This work was carried out with financial support of the UMNIK program of Russian Foundation for Assistance to Small Innovative Enterprises (FASIE) "Development of anticorrosive composition based on trialkoxysilanes and organic inhibitors for the protection of metal products from atmospheric corrosion during transportation and storage," Contract No. $9458 \mathrm{GU} / 2015$ as of 28.12.2015.

\section{References}

1. M.W. Kendig and R.G. Buchheit, "Corrosion inhibition of aluminum and aluminum alloys by soluble chromates, chromate coatings, and chromate-free coatings," Corrosion, 2003, 59, no. 5, 379-400.

2. Yu.I. Kuznetsov, Organic Inhibitors of Corrosion of Metals, 1996, New York and London, Plenum Press, 283 pp.

3. Yu.I. Kuznetsov, "Organic corrosion inhibitors: where are we now? A review. Part I. Adsorption," Int. J. Corros. Scale Inhib., 2015, 4, no. 4, 284-310. doi: 10.17675/2305$\underline{\text { 6894-2015-4-4-1 }}$

4. Yu.I. Kuznetsov, "Organic corrosion inhibitors: where are we now? A review. Part II. Passivation and the role of chemical structure of carboxylates," Int. J. Corros. Scale Inhib., 2016, 5, no. 4, 282-318. doi: 10.17675/2305-6894-2016-5-4-1

5. O.V. Karavai, A.C. Bastos, M.L. Zheludkevich, M.G. Taryba, S.V. Lamaka and M.G.S. Ferreira, "Localized electrochemical study of corrosion inhibition in 
microdefects on coated AZ31 magnesium alloy," Electrochim. Acta, 2010, 55, no. 19, 5401-5406.

6. U. Rammelt, S. Kohler and G. Reinhard, "EIS characterization of the inhibition of mild steel corrosion with carboxylates in neutral aqueous solution," Electrochim. Acta, 2008, 53, no. 23, 6968-6972.

7. Yu.I. Kuznetsov, A.A. Chirkunov, A.S. Gorbachev and N.P. Andreeva, "Passivation of mild steel by sodium octylphosphonate in neutral aqueous solution," Int. J. Corros. Scale Inhib., 2017, 6, no. 3, 318-332. doi: 10.17675/2305-6894-2017-6-3-7

8. Yu.I. Kuznetsov, "New possibilities of metal corrosion inhibition by organic heterocyclic compounds," Int. J. Corros. Scale Inhib., 2012, 1, 3-15. doi: 10.17675/2305-6894-2012-1-1-003-015

9. S.M. Milic and M.M. Antonijevic, "Some aspects of copper corrosion in presence of benzotriazole and chloride ions," Corros. Sci., 2009, 51, no. 1, 28-34.

10. Yu.I. Kuznetsov, N.P. Andreeva and M.O. Agafonkina, "Adsorption and protecting properties of 1,2,3-benzotriazole on MNZh 5-1 alloy in neutral solutions," Russ. J. Electrochem., 2014, 50, no. 10, 989-993.

11. G. Trabanelli, A. Frignani, C. Monticelli and F. Zucchi, "Alkyl-benzotriazole derivatives as inhibitors of iron and copper corrosion," Int. J. Corros. Scale Inhib., 2015, 4, no. 1, 96-107. doi: 10.17675/2305-6894-2015-4-1-096-107.

12. Yu.I. Kuznetsov, N.P. Andreeva and G.Yu. Kazanskaya, "On the inhibition effect of dialkyl phosphates in the depassivation of metals," Prot. Met. Phys. Chem. Surf., 2000, 36, no. 4, 351-355.

13. S.V. Oleynik, Yu.A. Kuzenkov, N.P. Andreeva and Yu.I. Kuznetsov, "Chromate-free pigments for the protection of aluminum alloy D16," Korroz.: Mater., Zashch., 2008, no. 3, 29-34 (in Russian).

14. A.A. Chirkunov, A.M. Semiletov, Yu.I. Kuznetsov and N.P. Andreeva, "Passivation of steel with aqueous solutions of trialkoxysilanes," Prot. Met. Phys. Chem. Surf., 2015, 51, no. 7, 1154-1159.

15. M.A. Petrunin, L.B. Maksaeva, T.A. Yurasova, E.V. Terekhova, V.A. Kotenev and A.Yu. Tsivadze, "Adsorption of alkoxysilanes on aluminum surface from aqueous solutions," Prot. Met. Phys. Chem. Surf., 2013, 49, no. 6, 655-661.

16. A.M. Beccaria and L. Chiaruttini, "The inhibitive action of metacryloxypropylmethoxysilane (MAOS) on aluminium corrosion in $\mathrm{NaCl}$ solutions," Corros. Sci., 1999, 41, no. 5, 885-899.

17. F. Frignani, F. Zucci, G. Trabanelli and V. Grassi, "Protective action towards aluminium corrosion by silanes with a long aliphatic chain," Corros. Sci., 2006, 48, no. 8, 2258-2273.

18. A.V. Agafonkin, Yu.I. Kuznetsov and N.P. Andreeva, "Formation of protective nanolayers on metals by N-benzylbenzylideneimine and (3-aminopropyl)triethoxysilane from gas phase," Korroz.: Mater., Zashch., 2010, no. 8, 24-30 (in Russian). 
19. G. Boiser, N. Portail and N. Pebere, "Corrosion inhibition of 2024 aluminium alloy by sodium decanoate," Electrochim. Acta, 2010, 55, no. 21, 6182-6189.

20. Q. Wang, B. Zhang, M. Qu, J. Zhang and D. He, "Fabrication of superhydrophobic surfaces on engineering material surfaces with stearic acid," Appl. Surf. Sci., 2008, 254, no. 7, 2009-2012.

21. Y. Yin, T. Liu, S. Chen, T. Liu, and S. Cheng, "Structure stability and corrosion inhibition of super-hydrophobic film on aluminum in seawater," Appl. Surf. Sci., 2008, 255, no. 5-2, 2978-2984.

22. Yu.M. Zimina, Yu.A. Kuzenkov and S.V. Oleynik, "Protective conversion coatings IFKhANAL on aluminum alloys," Korroz.: Mater., Zashch., 2010, no. 7, 44-48 (in Russian).

23. S.V. Oleynik, V.S. Rudnev, Yu.A. Kuzenkov, T.P. Yarovaya, L.F. Trubetskaya and P.M. Nedozorov, "Modified PEO coatings on aluminum alloys by corrosion inhibitors," Korroz.: Mater., Zashch., 2012, no. 11, 36-41 (in Russian).

24. Yu.I. Kuznetsov, "Progress in corrosion inhibition of metals and modification of protective nanolayers on metals," Korroz.: Mater., Zashch., 2011, no. 1, 1-10 (in Russian).

25. A.M. Semiletov, A.A. Chirkunov, Yu.I. Kuznetsov and N.P. Andreeva, "Improving steel passivation with aqueous solutions of [3-(2-Aminoethylamino)propyl]trimethoxysilane," Russ. J. Phys. Chem. A, 2015, 89, no. 12, 2271-2277. 